Agro-Science Journal of Tropical Agriculture, Food, Environment and Extension Volume 18 Number 3 (September 2019) pp. 42-47

ISSN 1119-7455

\title{
SOIL CONSERVATION PRACTICES AMONG RURAL FARMERS IN ARABLE CROP PRODUCTION IN OMUMA LOCAL GOVERNMENT AREA OF RIVERS STATE, NIGERIA
}

\author{
${ }^{* 1}$ Elenwa C.O. and ${ }^{2}$ Emodi A.I. \\ ${ }^{1}$ Department of Agricultural Extension \& Rural Development, \\ Rivers State University, Port Harcourt, Nigeria \\ ${ }^{2}$ Department of Agricultural Economics \& Extension, \\ University Port Harcourt, Port Harcourt, Nigeria \\ *Corresponding author's email: carobinedo@yahoo.com
}

\begin{abstract}
The study examined soil conservation practices in arable crop production among rural farmers in Omuma Local Government Area of Rivers State, Nigeria. Data were collected with the use of a questionnaire and interview schedule. One hundred and twenty respondents were selected from six communities using the simple random sampling technique. Data were analyzed using descriptive and inferential statistics such as the ordinary least square (OLS) analysis. Findings show that more than half $(52.5 \%)$ were married and 37.5\% had formal education. The mean age was 41 years. Types of soil conservative practices used were mulching (51.17\%), bush fallowing (59.17), manure application (32.50\%), planting indigenous crops (59.17), crop rotation (59.17\%), agro-forestry (8.33\%), cover cropping (32.50\%), intercropping (59.17\%), multicropping (58.33\%) and shifting cultivation (55.00\%), while mulching $(\bar{x}=75)$, bush fallowing $(\bar{x}=0.82)$, planting of indigenous plants $(\bar{x}=1.60)$, and crop rotation $(\bar{x}=1.58)$ were adopted. Benefits of soil conservation practices to arable crop farmers were improved soil structure (16.67\%), protection of soil from erosion and nutrients loses (16.67\%) among others. The major constraint to the use of soil conservation practices in arable crop production was unfavourable land tenure system (40.00\%). The study concluded that some soil conservation practices are adopted and practiced by arable crop farmers in the study area. The study further recommends that rewards and planting materials should be given to arable crop farmers as incentives in motivating them to adopt soil coservation practices.
\end{abstract}

Key words: soil conservation practices, arable crop, farmers

\section{INTRODUCTION}

Soil is the most important resources on which sustainable agriculture and livelihood of the agricultural productivity of the farm household. No less than a quarter of the world's population have farm household and most of which are in less developed countries of the world, Nigeria inclusive (Ellis, 2000). Hence, there is increased pressure on the available soil for food production most especially among developing nations of the world. Food and Agricultural Organization (FAO) (2007) affirmed that the use of soils for agricultural production is one of the strongest influences affecting environmental quality in many developing countries. Specifically, practices like unguided application of agrochemicals, bush burning, deforestation, grazing, continuous tillage and uncontrolled farm mechanization affect the quality of soil and vegetation cover, thereby resulting into soil degradation (Obalum et al., 2012).
Soil degradation is a phenomenon that is either natural or human-induced. Asadu et al. (2004) grouped soil degradation into soil erosion, soil infertility and soil pollution by soil spillage and industrial waste. Soil degradation is accelerated when the forest cover is removed, pastures are overgrazed and overall land use pattern are not sustainable. In Nigeria and other African countries, this phenomenon is being hastened by reduction in fallow periods and the shift from conventional bush fallowing system to permanent cultivation caused by population pressure and agricultural activities (Ameyan and Ogidiolu, 2002).

Decline in agricultural productivity as a result of soil degradation is evaluated in terms of such inputs as fertilizer/manuring, tillage methods and water management to boost production (Mbagwu, 2003). Due to changing human needs and competition for different uses of land, there is need for systematic land use and sustainable soil conservation practices. 
Amos (2010) opined that the productivity of agricultural lands should be boosted by guarding them against losses arising from compaction, erosion and decline of organic matter. Good soil conservation practice must be profitable as well as anchored on sound scientific principles and simultaneously meet the needs of the society. It involves the application of soil practices that are economically viable, socially acceptable, environmentally friendly and technically appropriate for planting ofarable crops (George, 2013). Arable crops are herbaceous plants produced under a more or less intensive cultivation (Phillips et al., 2008). Example of arable crops are sorghum, millet, cowpea, groundnut cassava, maize, yam and vegetable like fluted pumpkin. In Rivers State, the most cultivated arable crops are cassava, maize, cocoyam, okra and fluited pumpkin.

Junge et al. (2009) noted that effective soil conservation practices are neccessary to maintain substainable arable crop prouction. They classified conservation practices into three major strategies. These strategies include soil management, mechanical and agronomic soil conservation strategies; at the community and government levels, soil conservation measures are soil management and mechanical-based such as fencing, gully control, river bank protection, trail improvement, community based irrigation schemes, afforestation, construction of water ways, supply of fertilizer inputs to farmers at subsidized rate, construction of drainage among others (Igbokwe, 1996). Whereas at the farm level, Mbagwu (2003) observed that agronomic soil conservation strategies such as mulching and crop management practices such as cover cropping, fallowing, multiple cropping, intercropping planting pattern and crop rotation promote farm household capacity to cope with the threat of soil degradation and its associated low crop yield.

In Rivers State and Omuma LGA in particular, where most of the cultivable soil are degraded due to excessive deforestation, rapid urbanization and other economic activities that threaten the natural environment. Also, flood, drought, water pollution and erosion of agricultural land cause soil degradation. Efforts aimed at bridging food production to meet the need of the growing population have made rural farmers in arable crop production to engage in soil conservation practices ike cover cropping. Therefore, there is need to investigate how soil conservation practices among rural farmers have enhanced arable crop production in the study area. The study specifically sought to (i) describe the socio-economic characteristics of arable crop farmers; (ii) ascertain the types of soil conservation practices used in arable crops production; (iii) examine the benefits of soil conservation practices; and (iv) identify the constraints to the use of soil conservation practices in arable crop production in the study area.

\section{MATERIALS AND METHODS}

The study was carried out in Omuma Local Government Area (LGA) of Rivers State, Nigeria. The headquarters of the LGA is Eberi, it has an area of $170 \mathrm{~km}^{2}$. The LGA is bounded on the north by Imo State, on the South by Obio-Akpo LGA, on the east by Abia State and to the west by Ikwere LGA. Omuma LGA is one of the LGAs that make up the 23 LGAs of Rivers State, Omuma comprises six communities namely Owaza, Eberi, Umuechem, Afam, Egbelu and Umuebele which are located in the North southern part of the state. These communities are known for agricultural practices. The LGA has large massive land that is good for the cultivation of arable crops. The traditional occupation of the people of Omuma is farming; they produce arable crops such as cassava, maize, yam, cocoyam, fluted pumpkin, okra, etc.

First, all the communities in Omuma LGA were were purposively selected because they are all involved in arable crop production. Secondly, simple random sampling was used to select arable crop farmers from the six communities: Owaza-18, Eberi-19, Umuechem-22, Afam-23, Egbelu-17 and Umuebele-21, giving a total of 120 respondents. Data were collected through primary source using questionnaire and interview schedule. Data collected from the respondents were presented using descriptive statistics such as mean score, table, percentage and frequencyand regression analysis was used to anaiyse the data. Also, a three-point Likert type scale was used with options: fully adopted (2); partially adopted (1); not adopted (0) which gave a mean score of 1.00. Variables equal to and greater than 1.00 were considered as a adopted while variables that had below 1.00 were seen as partially adopted. The coefficient of determination $\left(\mathrm{R}^{2}\right)$ was used to ascertain the fitness of the model. The hypthesis was tested at probability value ( $\mathrm{pv}<0.05)$ level of significance, reject the null and if the $\mathrm{pv}>0.05$ accept.

$$
\mathrm{y}=\mathrm{bo}+x_{1}+x_{2}+x_{3}+x_{4}+\ldots \mathrm{e}
$$

where $\mathrm{y}$ is soil conservation practices, $x_{1}$ is sex (female $=0$; male $=1$ ), $x_{2}$ is age (years), $x_{3}$ is education level (number of years spent), $x_{4}$ is secondary occupation, $x_{5}$ is household size (persons), $x_{6}$ is farming experience (years), $x_{7}$ is monthly income, and e is stochastic error term.

\section{RESULTS AND DISCUSSION}

Socio-Economic Characteristics of Respondents The results in Table 1 show that high number $(36.70 \%)$ of the respondents were between the age brackets of 40-49. The mean age is 41.3 years indicating that the farmers involved in arable crop production are active, young, vibrant farmers who are in there productive stage. This disagrees with Albert et al. (2015) who observed that the majority of arable crop farmers in Ahoada East were aged $50-60$ years. More than half $(51.67 \%)$ of the arable 
Table 1: Socio-economic characteristics of arable crop farmers

\begin{tabular}{|c|c|c|c|}
\hline Variables & $\begin{array}{l}\text { Frequency } \\
(n=120)\end{array}$ & Percentage & Mean \\
\hline \multicolumn{4}{|l|}{ Age (years) } \\
\hline $20-29$ & 18 & 15.00 & \\
\hline $30-39$ & 30 & 25.00 & \\
\hline $40-59$ & 44 & 36.70 & 41.3 years \\
\hline $50-59$ & 28 & 23.30 & \\
\hline \multicolumn{4}{|l|}{ Sex } \\
\hline Male & 58 & 48.33 & \\
\hline Female & 62 & 51.67 & \\
\hline Total & 120 & 100.00 & \\
\hline \multicolumn{4}{|l|}{ Marital status } \\
\hline Married & 63 & 52.50 & \\
\hline Single & 13 & 10.83 & \\
\hline Divorced & 17 & 14.17 & \\
\hline Widow & 27 & 22.50 & \\
\hline \multicolumn{4}{|c|}{ Household size (Persons) } \\
\hline $1-4$ & 78 & 65.00 & \\
\hline $5-8$ & 40 & 33.33 & \\
\hline $9-12$ & 2 & 1.67 & \\
\hline $13-16$ & - & - & \\
\hline Total & 120 & 100.00 & 4 persons \\
\hline \multicolumn{4}{|l|}{ Educational Level } \\
\hline No formal Education & 36 & 30.00 & \\
\hline Primary & 45 & 37.50 & \\
\hline Secondary & 39 & 32.50 & \\
\hline Tertiary & 0 & 0.0 & \\
\hline Total & 120 & 100.00 & \\
\hline \multicolumn{4}{|l|}{ Farming experience } \\
\hline $1-10$ & 16 & 13.34 & \\
\hline $11-20$ & 46 & 38.33 & \\
\hline $21-30$ & 40 & 33.33 & 20.5 years \\
\hline $31-40$ & 18 & 15.00 & \\
\hline \multicolumn{4}{|l|}{ Monthly income ( } \\
\hline$>5,000-10,000$ & 2 & 1.67 & \\
\hline $11,000-20,000$ & 6 & 5.00 & \\
\hline $21,000-30,000$ & 44 & 36.67 & \\
\hline $31,000-40,000$ & 52 & 43.33 & \\
\hline $41,000-50,000$ & 10 & 8.33 & \\
\hline $51,000-60,000$ & 6 & 5.00 & $¥ 32.201$ \\
\hline \multicolumn{4}{|l|}{ Secondary occupation } \\
\hline Farming & 92 & 76.67 & \\
\hline $\begin{array}{l}\text { Self-employed/ } \\
\text { Petty trader }\end{array}$ & 20 & 16.67 & \\
\hline $\begin{array}{l}\text { Civil/public } \\
\text { service }\end{array}$ & 8 & 6.66 & \\
\hline
\end{tabular}

Source: Field Survey, 2018

farmers were females while $48.33 \%$ were male which means that female dominated arable crop production in the study area. Females were mostly into vegetable, pepper, okra and maize production while the males grow yam. This agrees with Albert and Okidim (2014) who observed that female arable crop farmers in Ahoada East were into the production of maize, pepper and flunted pumpkin. More than half $(52.50 \%)$ of the respondent were married. This implies that arable crop farmers were married and had the responsibility of helping their husbands to provide the basic needs of the family. According to Albert and Nne-cosy (2014), marriage makes people to show sense of responsibility towards the family in the area of taking care of the children and meeting family needs. The percentage (70\%) of arable crop farmers who could read and write was high. This implies that arable crop farmers are literate. This will encourage and motivate them to adopt soil conservative practices that will help to improve yeilds and increase output. The mean years of farming experience was 20.5 years. This indicates that the arable crops farmers have been long in the field of farming and therefore will have enough knowledge on soil conservative practices used in arable crop production and to give a good and accurate account of the ones adopted and its challenges. Albert et al. (2013) stated that years of experience help in giving account of events.

The effectof the socio economic characteristics of arable crop farmers onthe use of soil conservation practices is shown in Table 2 . The $\mathrm{R}^{2}$ was 0.791 indicating that $79 \%$ of the independent varaibles were explained in the deoendent varaible. Gender had a probability value of $(\mathrm{PV}=0.000<0.05$ level of significance) indicating a relationship with soil conservation practices as f-cal $=219.6>$ f-tab $=$ 2.72. Age ( $\mathrm{PV}=0.000<0.05$ level of significance), had an effect on soil conservation practices at f-cal $=219.6>\mathrm{f}$-tab $=2.72$. Household size $(\mathrm{PV}=0.000$ $<0.05$ level of significance) had an effect on soil conservation practices as $\mathrm{f}$-cal $=219.6>\mathrm{f}$-tab $=$ 2.72. Farming experience ( $\mathrm{PV}=0.000<0.05$ level of significance) had an effect on soil conservation practices as f-cal $=219.6>\mathrm{f}$-tab $=2.72$. Monthly income $(\mathrm{PV}=0.000<0.05$ level of significance $)$ had an effect on soil conservation practices as f-cal $=219.6>$ f-tab $=2.72$. Education $(\mathrm{PV}=0.000>$ 0.05 level of significance) had no effect on soil conservation practices as f-cal $=219.6>\mathrm{f}$-tab $=$ 2.72 , also secondary occupation $(\mathrm{PV}=0.000>$ 0.05 level of significance) had no effect on soil conservation practices as $\mathrm{f}$-cal $=219.6>\mathrm{f}$-tab $=$ 2.72. Hence the null hypothesis is accepted.

\section{Awareness of Soil Conservative Practices among Arable Crop Farmers}

Majority (59.17\%) each of the respondents accepted that they are aware of mulching, bush fallowing, planting of indigenous plants, crop rotation and intercropping (Table 3). While 58.33\% and $55 \%$ agreed that they are aware of multicropping and shifting cultivation, respectively. Followed by the respondents that said they are aware of all of the above mention conservative practices $(40.33 \%)$ and $32.50 \%$ each are aware of manure application and cover cropping were also practiced. Agroforestry was the least awared practice (8.33\%). These results indicate that mulching, bush fallowing, planting of indigenous plants, crop rotation, multicropping, shifting cultivation, manure application, cover cropping and intercropping were the soil conservative practices arable crop farmers were aware of in the study area. 
Table 2: Relationship between the socio-economic characteristics of rural dwellers and food consumption

\begin{tabular}{|c|c|c|c|c|c|c|c|c|}
\hline Variables & Coefficient & $\mathrm{t}$-cal & $\mathrm{t}-\mathrm{tab}(0.05,119)$ & $\mathrm{R}$ & $\mathrm{R}^{2}$ & F-cal & F-tab & Sig F \\
\hline (Constant) & -4.10 & -14.82 & \multirow{8}{*}{2.13} & \multirow{8}{*}{0.865} & \multirow{8}{*}{0.791} & \multirow{8}{*}{219.6} & \multirow{8}{*}{2.72} & \multirow{8}{*}{0.000} \\
\hline Gender & 1.62 & $4.535^{*}$ & & & & & & \\
\hline Age & 0.43 & $4.614^{*}$ & & & & & & \\
\hline Education & -0.210 & $-1.643^{* *}$ & & & & & & \\
\hline Sec. Occupation & 0.091 & $1.652^{* *}$ & & & & & & \\
\hline Household Size & 0.475 & $5.297^{*}$ & & & & & & \\
\hline Farming Experience & 0.713 & $6.779^{*}$ & & & & & & \\
\hline Monthly income & 0.643 & $6.389^{*}$ & & & & & & \\
\hline
\end{tabular}

Table 3: Awareness of soil conservative practices among arable crop farmers

\begin{tabular}{lll}
\hline $\begin{array}{l}\text { Types of soil conservative } \\
\text { practices }\end{array}$ & $\begin{array}{l}\text { Frequency } \\
(n=120)\end{array}$ & Percentage \\
\hline Mulching & 71 & 59.17 \\
Bush Fallowing & 71 & 59.17 \\
Manure Application & 39 & 32.50 \\
Planting indigenous crops & 71 & 59.17 \\
Crop rotation & 71 & 59.17 \\
Agro-forestry & 10 & 8.33 \\
Cover cropping & 39 & 32.50 \\
Intercropping & 71 & 59.17 \\
Multicropping & 70 & 58.33 \\
Shifting cultivation & 66 & 55.00 \\
All of the above & 49 & 40.33 \\
\hline
\end{tabular}

Source: Field Survey, 2018; multiple responses

\section{Soil Conservation Practices Adopted by Arable Crop Farmers}

Using a mean score of 1.00 as the desicion rule, the data in Table 4 show that almost all the soil conservative practices in the study area were adopted by the arable crop farmers except for agroforstery with a mean score of 0.93 that was partially adopted. This implies that mulching $(\overline{\boldsymbol{x}}=1.75)$, bush fallowing ( $\bar{x}=1.82$ ), planting of indigenous plants $(\bar{x}=1.60)$, crop rotation $(\bar{x}=1.58)$, planting pattern $(\bar{x}=1.46)$, multicropping $(\bar{x}=1.25)$, shifting cultivation ( $\bar{x}=1.16)$, manure application $(\bar{x}=1.15)$, cover cropping $(\bar{x}=1.63)$ and intercropping $(\bar{x}=$ 1.54) were adopted. Mulching, bush fallowing, planting of indigenous crops, crop rotation, planting pattern, multicropping, shifting cultivation, manure application, cover cropping and intercropping are soil conservative practices adopted by rural arable crop farmers in the study area. Agronomic measures such as mulching and crop management (cover cropping, fallowing, multiple cropping, intercropping planting pattern and crop rotation) are measures used to enhance the quality of degraded soils (Junge et al., 2009; Obalum and Obi, 2010).

\section{Benefits of Soil Conservative Practices to Arable Crop Farmers}

Majority (83.3.3\%) of the respondents accepted that all the varaiables mentioned were benefits of the use of soil conservative practices by arable crop farmers in the study area (Table 5). This is followed by the respondents that were of the view that it improves soil structure $(16.67 \%)$, protects soil from erosion and nutrient losses (16.67\%), ensures less water usage $(16.67 \%)$, and enhances water holding capacity $(16.67 \%)$, while $15.83 \%$ and $15.00 \%$ said it reduces labour requirement, improves productivity, protects soil from extreme temperature and reduces evaporation. The use of soil conservative practices by arable crop farmers heps to improve soil structure, protect soil from erosion and nutrients loses, leads to less water useage and enhance water holding capacity. The soil loses some of its chemical, physical and organic qualities and thereby becomes less productive. Practing soil conservation helps to enhance soil structure and fertility and the ability of soil to nourish and support optimum growth of arable crops (Uzokwe, 2000).

Table 4: Soil conservative practices adopted by arable crop farmers

\begin{tabular}{|c|c|c|c|c|c|c|c|}
\hline $\mathrm{S} / \mathrm{N}$ & $\begin{array}{l}\text { Soil conservative practices } \\
\text { adopted } \quad(n=120)\end{array}$ & $\begin{array}{c}\text { Full } \\
\text { Adopted (2) }\end{array}$ & $\begin{array}{c}\text { Partially } \\
\text { Adopted (1) }\end{array}$ & $\begin{array}{c}\text { Not } \\
\text { Adopted (0) } \\
\end{array}$ & $\begin{array}{l}\text { Total } \\
\text { Score } \\
\end{array}$ & $\begin{array}{c}\text { Mean } \\
\text { Score } \bar{x}\end{array}$ & Remark \\
\hline 1 & Mulching & 100 & 10 & 10 & 210 & 1.75 & A \\
\hline 2 & Bush Fallowing & 100 & 18 & 2 & 218 & 1.82 & A \\
\hline 3 & Manure Application & 90 & 16 & 24 & 196 & 1.63 & A \\
\hline 4 & Planting indigenous crops & 90 & 12 & 18 & 192 & 1.60 & A \\
\hline 5 & Crop rotation & 80 & 30 & 10 & 190 & 1.58 & A \\
\hline 6 & Agro-forestry & 32 & 48 & 40 & 112 & 0.93 & PA \\
\hline 7 & Cover cropping & 48 & 42 & 30 & 138 & 1.15 & A \\
\hline 8 & Planting pattern & 75 & 25 & 20 & 175 & 1.46 & A \\
\hline 9 & Intercropping & 85 & 15 & 20 & 185 & 1.54 & A \\
\hline 10 & Multi-cropping & 60 & 30 & 30 & 150 & 1.25 & A \\
\hline \multirow[t]{2}{*}{11} & Shifting cultivation & 50 & 40 & 30 & 140 & 1.16 & A \\
\hline & Grand Mean & & & & & 1.44 & A \\
\hline
\end{tabular}

Source: Field Survey, 2018; $\geq 1.00$ - Adopted, $<1.00$ - Partially Adopted 
Table 5: Benefits of soil conservative practices to arable crop farmers

\begin{tabular}{lc}
\hline Benefits of soil conservative practices & Percentage \\
\hline Improve soil structure & 16.67 \\
Protect soil from erosion and nutrients loses & 16.67 \\
Less water useage & 16.67 \\
Enhance water holding capacity & 16.67 \\
Protect soil from extreme temperature & 15.0 \\
Reduce evaporation & 15.0 \\
Improve productivity & 15.83 \\
Reduce labour requirement & 15.83 \\
All of the above & 83.33 \\
\hline
\end{tabular}

Source: Field Survey, 2018; multiple responses

Constraints to the Use of Soil Conservative Practices by Arable Crop Farmers

Majority (60\%) of the respondents accepted that all the varaiables mentioned were constraints to the use of soil conservative practices by arable crop farmers in the study area (Table 6). The result further showed that respondents were of the view that unfavourable land tenure system $(40 \%)$, lack of incentives (40\%), cultural barrier $(40 \%)$, unavailability of information $(40 \%)$, inadequate soil conservation skills (40\%), and little road access to land (40\%) were constraints to the use of soil conservative practices while $(39.17 \%)$ and $(11.67 \%)$ said it was lack of technical knowhow and insufficient farm labour, respectively. Only 9.17\% indicated population pressure on land as a cnstraint. It means that unfavourable land tenure system, lack of incentives, cultural barrier, unavailability of information, inadequate soil conservation skills and little road access to land were the constraints to the use of soil conservative practices in the study area. The result confims the observation of Elenwa et al. (2019) that cultural barrier has affected the use and adoption of technologies including the use of soil conservation practices.

Table 6: Constraints to the use of soil conservation practices by arable crop farmers

\begin{tabular}{lcc}
\hline Constraints & $\begin{array}{c}\text { Frequency } \\
(n=120)\end{array}$ & Percentage \\
\hline Unfavourable land tenure system & 48 & 40.00 \\
Lack of incentives & 48 & 40.00 \\
Cultural barrier & 48 & 40.00 \\
Unavailability of information & 48 & 40.00 \\
Population pressure on land & 11 & 9.17 \\
Lack of technical knowhow & 47 & 39.17 \\
Inadequate soil conservation skills & 48 & 40.00 \\
Little road access to land & 48 & 40.00 \\
Insufficient farm labour & 14 & 11.67 \\
All of the above & 72 & 60.00 \\
\hline Sourre: Fleld Survey, 2018; multiple responses
\end{tabular}

Source: Field Survey, 2018; multiple responses

\section{Conclusion}

There are soil conservation practices adopted and practiced by arable crop farmers in the study area. The major socio-economic influencing the use of soil conservation practices in the area were gender, age, household size, farming experience and monthly income. At the farmers' level, the identified factors militating against arable crop production include: unfavourable land tenure system, lack of incentives, cultural barrier, unavailability of information, lack of technical knowhow, inadequate soil conservation skills and little road access to land. The choice of conservative method practiced on the soil, could help to address a lot of environmental issues such as climate change and ensure food sustainability to meet up the teeming population. Based on the findings of this study, the following suggestions were made: Good road network should be put in place to link the arable crop farmers with market place thereby controlling damage and loss incured due to poor road condition. The government should enhance access of arable crop farmers to cultivable land through favourable policies.

\section{References}

Adamu A. (2004). Nigeria National Agricultural Research Strategy (1996-2010). Ibadan: Inter Printers Limited

Albert C.O., Nnodim A.U. and Cookey A.T. (2013). Analysis of skills acquisition programme (SAP) on employment opportunities in rural Rivers State. Journal of Research on Humanities and Social Sciences, 3 (9), 106-109

Albert C.O. and Okidim A.I. (2014). Climate change variability and mitigating measures by rural dwellers: The perception of arable farmers. Journal of Agricultural Science, 6 (1), 167-172

Albert C.O. and Nne-Cosy J. (2014). Analysis of family planning programmes among rural households in Ogba/Egbema/Ndoni Local Government Area of Rivers State, Nigeria. Agricultural Practice and Science Journal, 1-2 (89-90), 158-163

Albert C.O., Harry A.T and Ishikaku E. (2015). Constraints to adaptative strategies to climate change variability by farmers in Ahoada-East Local Government Area, Rivers State. Proceedings of $49^{\text {th }}$ Annual Conference of Agricultural Society of Nigeria, Delta State University, Delta State, pp. 261-264

Ameyan O. and Ogidiolu O. (2002). Agricultural land use and soil degradation in a part of Kwara State, Nigeria. Environmentalist, 9, 285-290

Amos E.M. (2010). The impact of land management practices on soil quality and implications on small holder productivity in southern highland, Tanzania. Journal of Environmental Economics, 1 (2),14-18

Asadu C.L.A., Ezeaku P.I. and Nnaji G.U. (2004). Land use and soil management situation in Nigeria: An analytical review of changes. Outlook on Agriculture, 33, 27-37

Blanco H. and Lal R. (2008). Principles of Soil Conservation and Management. Columbus: Springer

Elenwa C.O., Isife B.I. and Nkoro F.O. (2019). Indigenous mushroom harvesting and strategies among rural women in Ikwerre Kingdom, Rivers State, Nigeria. Journal of Agricultural Extension, 23 (1), 105-112 
Ellis F. (2000). Farm Households and Agarian Development. Cambridge University Press, Cambridge Food and Agricultural Organization (FAO) (2007). Conservation agriculture. Department of Agriculture and Consumer Protection. Food and Agriculture Organization (FAO), Rome

George J.H. (2013). Sustainable Agricultural Land Management Practices of Arable Crop Farmers in Florida. University of Florida, pp. 19-25

Igbokwe E.M. (1996). A soil and water conservation system under threat: a visit to Maku, Nigeria. In: Reij C., Scoones I. and Toulmin C. (eds.) Sustaining the SoilIndigenous Soil and Water Conservation in Africa. Earthscan Publication, London, UK, pp. 219-343

Junge B., Deji O., Abaidoo R., Chikoye D. and Stahr K. (2009). Farmers' adoption of soil conservation technologies: A case study from Osun State, Nigeria. Journal Agriculture Education Extension, 15, 257-274

Mbagwu J.S.C. (2003). Aggregate stability and soil degradation in the tropics. Lecture given at the College of Soil Physics Trieste, Italy
Morgan R.P.C. (1995). Soil Erosion and Soil Conservation. Longman Publishers Ltd, Essex

Obalum S.E. and Obi M.E. (2010). Physical properties of a sandy loam Ultisol as affected by tillage-mulch management practices and cropping systems. Soil and Tillage Research, 108 (1-2), 30-36

Obalum S.E., Buri M.M., Nwite J.C., Hermansah, Watanabe Y., Igwe C.A. and Wakatsuki T. (2012). Soil degradation-induced decline in productivity of sub-Saharan African soils: theprospects of looking downwards the lowlands with the sawah ecotechnology. Applied and Environmental Soil Science, Volume 2012, Article ID 673926, 10 pages.doi:10.1155/2012/673926

Uzokwe U.N. (2000). The Effect of Soil on Income Generating Activities of Women in Anambra State. A $\mathrm{PhD}$ Thesis in the Department of Agriculture Extension, University of Ibadan, Ibadan, Nigeria

Yahaya M.K. and Olajide R.B. (2002). The impact of agriculture on environmental health. Journal of Environmental Extension, 3 (1), 47-57 